F. ZHANG, Y. WEI, X. WU, H. JIANG, W. WANG, * H. LI* (SHANGHAI NORMAL UNIVERSITY, P. R. OF CHINA AND UNIVERSITY OF NEW MEXICO, ALBUQUERQUE, USA)

Hollow Zeolitic Imidazolate Framework Nanospheres as Highly Efficient Cooperative Catalysts for [3+3]

Cycloaddition Reactions

J. Am. Chem. Soc. 2014, 136, 13963-13966.

\title{
A Zeolitic Imidazolate Framework Catalyst for [3+3] Cycloadditions
}<smiles>CC1C(=O)CC(=O)C(C)C1C1CCCC1</smiles>

$(1 \mathrm{mmol})$

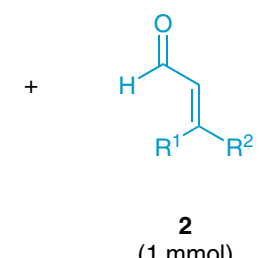

$(1 \mathrm{mmol})$
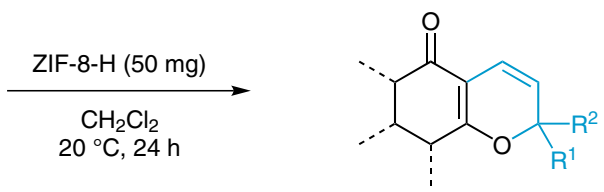

3

Selected examples:<smiles>CC1(C)C=CC2=C(CCCC2=O)O1</smiles>

$89.0 \%$ conversion $99.9 \%$ selectivity<smiles>CC(C)(C)CC1C=CC2=C(CCCC2=O)O1</smiles>

$76.7 \%$ conversion $99.9 \%$ selectivity<smiles>CC(C)=CCCC1(C)C=CC2=C(CCCC2=O)O1</smiles>

$65.4 \%$ conversion $99.9 \%$ selectivity<smiles>O=C1CCCc2oc(=O)ccc21</smiles>

$76.7 \%$ conversion $99.9 \%$ selectivity

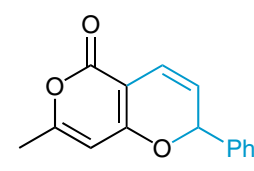

$47.5 \%$ conversion $99.9 \%$ selectivity

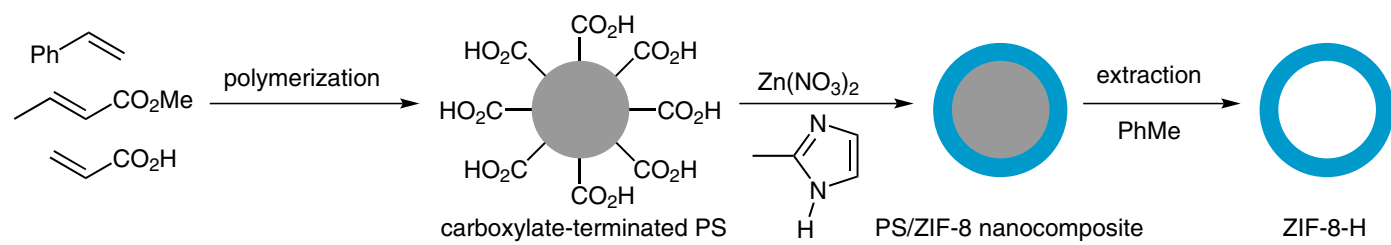

Significance: The authors developed a hollowstructured zeolitic imidazolate framework (ZIF-8$H)$ nanosphere as a catalyst for [3+3] cycloadditions. ZIF-8-H was prepared via complexation of carboxylic groups on the surface of nano-PS $(\varnothing=400 \mathrm{~nm}$ ) with zinc ions and 2-methylimidazole, followed by subsequent removal of the PS nanosphere by extraction with toluene. The reaction of 1,3-dicarbonyl compounds 1 with $\alpha, \beta$-unsaturated aldehydes 2 proceeded in the presence of ZIF-8-H to give the pyranyl heterocycles $\mathbf{3}$ with up to $89.0 \%$ conversion and $99.9 \%$ selectivity.
Comment: The reaction of 1,3-hexanedione and 3-methyl-2-butenal proceeded in the presence of ZIF-8-H with 89.0\% conversion, whereas the use of bulk ZIF-8 showed lower catalytic efficiency (73.2\% conversion). Toluene vapor adsorption isotherm showed that ZIF-8-H absorbed toluene to a cage-filling level with a high adsorption amount $(6.34 \mathrm{mmol} / \mathrm{g})$. Based on this observation, the authors discussed that the limiting aperture size of ZIF-8-H exceeded the kinetic diameter of toluene $(0.61 \mathrm{~nm})$, which is much larger than the reported window size of ZIF-8 (0.34 nm). 